\title{
Correlation between Infection with Multiple Respiratory Viruses and Length of Hospital Stay in Patients from Cheonan, Korea
}

\author{
Jae-Sik Jeon ${ }^{1}$, Jin-Wan Park ${ }^{2}$, Jae Kyung Kim ${ }^{3}$ \\ ${ }^{1}$ Department of Laboratory Medicine, Dankook University College of Medicine, Cheonan, Korea \\ ${ }^{2}$ Department of Obstetrics and Gynecology, College of Medicine, Dankook University, Cheonan, Korea \\ ${ }^{3}$ Department of Biomedical Laboratory Science, Dankook University College of Health Sciences, Cheonan, Korea
}

\section{천안 지역에서 호흡기 바이러스 감염과 병원 입원기간과의 관계}

전재식 ${ }^{1}$, 박진완 $^{2}$, 김재경 ${ }^{3}$

${ }^{1}$ 단국대학교 의과대학 임상병리학교실, ${ }^{2}$ 단국대학교 의과대학 산부인과학교실, ${ }^{3}$ 단국대학교 보건과학대학 임상병리학과

\begin{abstract}
The length of hospital stay (LOS) for patients with respiratory virus infections has been reported to depend the virus type and infection severity. However, the impact of co-infections remains unclear. Patients with suspected respiratory virus infections, who visited Dankook University Hospital between December 2006 and February 2014, were included to examine the relationship between co-infections and LOS. Multiplex reverse transcriptase-polymerase chain reactions were used to identify the causative viruses. LOS was analyzed with respect to sex, age, virus, and co-infection. During this period, 5,310 out of the 8,860 patients (59.9\%; median age, 1.5 years) were respiratory virus-positive. In respiratory virus-positive patients with single, double, and three-or-more infections, the average LOS was 7.3, 6.7, and 6.6 days, respectively. Longer LOS was observed for older patients and those with human coronavirus OC43 infections compared with adenovirus or respiratory syncytial virus $A$ infections. LOS differed significantly according to age, virus type, and co-infection, but not between double and three or more infections.
\end{abstract}

Key words: Coinfection, Human coronavirus OC43, Length of hospital stay, Polymerase chain reaction, Respiratory virus

\footnotetext{
This is an Open Access article distributed under the terms of the Creative Commons Attribution Non-Commercial License (http://creativecommons.org/licenses/by-nc/4.0) which permits unrestricted non-commercial use, distribution, and reproduction in any medium, provided the original work is properly cited.

Copyright @ 2017 The Korean Society for Clinical Laboratory Science. All rights reserved.
}

\author{
Corresponding author: Jae Kyung Kim \\ Department of Biomedical Laboratory Science, \\ Dankook University College of Health Sciences, \\ 119 Dandae-ro, Dongnan-gu, Cheonan 31116, \\ Korea \\ Tel: 82-41-550-1451 \\ Fax: 82-41-559-7934 \\ E-mail: nerowolf2@dankook.ac.kr
}

Received: January 3, 2017

Revised $1^{\text {st: }}$ January 25, 2017

Revised 2 ${ }^{\text {nd }}$ : February 2, 2017

Accepted: February 2, 2017

\section{INTRODUCTION}

Increased severity of viral infections has recently been reported to prolong the length of hospital stay (LOS). Further, the LOS may differ depending on the virus type [1]. However, controversy exists regarding whether these viruses increase the severity of illness and LOS [2]. It has been reported that, while co-infections do not affect LOS or mortality, influenza virus (INF) infection is associated with increased LOS and mortality [3,4]. Nonetheless, the impact of co-infections is, in general, still unclear [2,5-7]. This study examined whether the LOS for respiratory virus infections differed by sex, age, causative virus, or viral co-infection. 


\section{MATERIALS AND METHODS}

\section{Participants}

A total of 8,860 patients who were treated at Dankook University Hospital for respiratory symptoms between December 2006 and February 2014 were retrospectively included in the study. Patients were admitted either via the emergency department or via outpatient services. Molecular tests for the presence of respiratory viruses were performed on all patients.

\section{Ethical considerations}

The present study was approved by the institutional review board (IRB) of Dankook University (Date of IRB approval: 2015.10.13; IRB approval No.: 2015-09-009). The work described in this study has been carried out in accordance with The Code of Ethics of the World Medical Association (Declaration of Helsinki).

\section{Sample collection and extraction of viral nucleic acid}

Within 24 hours of admission, nasopharyngeal secretions were collected by inserting a mucus extractor, and connected to a sterile 8-French catheter (Sewoon Medical, Cheonan, Korea) $5 \sim 7 \mathrm{~cm}$ into the nostril and applying a suction pressure of 60 80 mmHg. Samples were stored at $4^{\circ} \mathrm{C}$ until nucleic acid extraction was performed. Nucleic acid extraction was performed using a QIAamp DNA Mini Kit (Qiagen, Hilden, Germany) - according to the manufacturer's protocol - using QIAcube (Qiagen, Hilden, Germany), which is automated equipment for nucleic acid extraction. The extracted nucleic acids were stored at $-70^{\circ} \mathrm{C}$ until the tests were performed.

\section{Respiratory virus detection}

Respiratory viruses were detected using multiplex reverse transcriptase-polymerase chain reactions (RT-PCR), which can simultaneously detect 12 types of respiratory virus. Ribonucleic acid (RNA) was isolated from nasopharyngeal secretions and reconstructed as complementary deoxyribonucleic acid (cDNA). The cDNA was then amplified with the Seeplex RV detection kit-1
(Seegene, Seoul, Korea) to test for one DNA virus, adenovirus (ADV), and 11 RNA viruses that cause respiratory infection: respiratory syncytial virus (RSV) A and B; INF A and B; parainfluenza virus (PIV) types 1, 2, and 3; human rhinovirus (HRV); human coronavirus (hCoV) NL63, and OC43; and human metapneumovirus (hMPV). PCR was performed using the PTC 200 PCR system (MJ Research, Watertown, MA, USA) with a program of 40 cycles of: $30 \mathrm{~s}$ at $94^{\circ} \mathrm{C}, 90 \mathrm{~s}$ at $60^{\circ} \mathrm{C}$, and $90 \mathrm{~s}$ at $72^{\circ} \mathrm{C}$, followed by $1 \mathrm{cycle}$ of $10 \mathrm{~min}$ at $72^{\circ} \mathrm{C}$. The amplified PCR products were analyzed after $30 \mathrm{~min}$ of electrophoresis at 100 150 V in $2 \%$ agarose gels stained with ethidium bromide.

\section{Statistical analysis}

Patient characteristics at the time of admission, including age, sex, and LOS, were analyzed retrospectively. A $p$-value by statistically analysis, $<0.05$ was considered to be significant.

\section{RESULTS}

Of 8,860 patients, 6,492 respiratory viruses were detected in 5,310 virus-positive patients. A total of 3,111 male and 2,199 female patients were positive for respiratory virus infections; their median age was 1.5 years (range, 2 days to 96.2 years, Table 1). Of the patients admitted to the hospital and referred for PCR testing for respiratory viruses, the average LOS among patients who tested positive was 7.2 days; 7.3 and 7.0 days for men and women, respectively ( $p=0.109$ ) (Table 2 ). The average LOS for the group of patients $0 \sim 10$ years of age was 6.5 days; however, the group aged 30 39 years was admitted for an average of 10.7 days, and the group aged 50 59 years was admitted for an average of 13.7 days, suggesting that age is related to longer LOS (Figure 1). Regression analysis showed a significant proportional relationship between LOS and age $(p<0.01)$.

Among single infections, infection with hCoV OC43 was associated with the longest LOS (10.1 days), followed by infection with INF A (8.9 days). ADV infections had the 
24 Jae-Sik Jeon, et al. Respiratory Viruses and Length of Hospital Stay

Table 1. Analysis of cases according to the respiratory infection type, including positive ratios and length of hospital stay

\begin{tabular}{lcccccc}
\hline \multicolumn{1}{c}{ Infection type } & No. of patients & Ratio, \% & Men & Women & $\begin{array}{c}\text { Median age } \\
\text { (average age) }\end{array}$ & $\begin{array}{c}\text { Average LOS, } \\
\text { days }\end{array}$ \\
\hline Submitted & 8,860 & 100.0 & 5,292 & 3,568 & $2.2(7.4)$ & \\
Positive & 5,310 & 59.9 & 3,111 & 2,199 & $1.5(9.3)$ & 7.2 \\
Single infection & 4,250 & 48.0 & 2,496 & 1,754 & $1.5(10.3)$ & 7.3 \\
Multiple infections & 1,060 & 12.0 & 615 & 445 & $1.4(5.1)$ & 6.7 \\
Double infections & 943 & 10.6 & 550 & 393 & $1.4(5.1)$ & 6.7 \\
Three or more infections & 117 & 1.3 & 65 & 52 & $1.5(5.2)$ & 6.6 \\
\hline
\end{tabular}

Abbreviation: LOS, length of hospital stay.

Table 2. Analysis of cases according to single respiratory virus type, including positive ratios and length of hospital stay

\begin{tabular}{lccc}
\hline Virus & No. of patients & $\begin{array}{c}\text { Length of } \\
\text { hospital stay, } \\
\text { days }\end{array}$ & Ratio, \%* \\
\hline INF A & 466 & 8.9 & 11.0 \\
INF B & 134 & 6.5 & 3.2 \\
RSV A & 803 & 7.3 & 18.9 \\
RSV B & 546 & 6.6 & 12.8 \\
hMPV & 305 & 7.6 & 7.2 \\
PIV 1 & 162 & 6.9 & 3.8 \\
PIV 2 & 49 & 6.3 & 1.2 \\
PIV 3 & 262 & 7.7 & 6.2 \\
HRV & 794 & 7.1 & 18.7 \\
hCoV NL63 & 117 & 7.2 & 2.8 \\
hCoV OC43 & 109 & 10.1 & 2.6 \\
ADV & 503 & 6.2 & 11.8 \\
\hline
\end{tabular}

*Number of each virus/Total positive number.

Abbreviation: INF, influenza; RSV, respiratory syncytial virus; hMPV, human metapneumovirus; PIV, parainfluenza virus; HRV, human rhinovirus; hCoV, human coronavirus; ADV, adenovirus.

shortest LOS, at 6.2 days (Table 2). The LOS for patients infected with hCoV OC43 was significantly different from that of patients infected with INF A virus $(p<0.03)$. Among patients positive for respiratory viruses, those with single infections had an average LOS of 7.3 days, compared with 6.7 days in patients with double infections and 6.6 days in patients with three or more identified respiratory viruses (Table 1). Differences in LOS between patients with single and the combined group of patients with double or three or more infections were statistically significant $(p<0.01)$. However, the difference between double infections and three or more infections was not significant (Table 1, $p=0.858$ ).

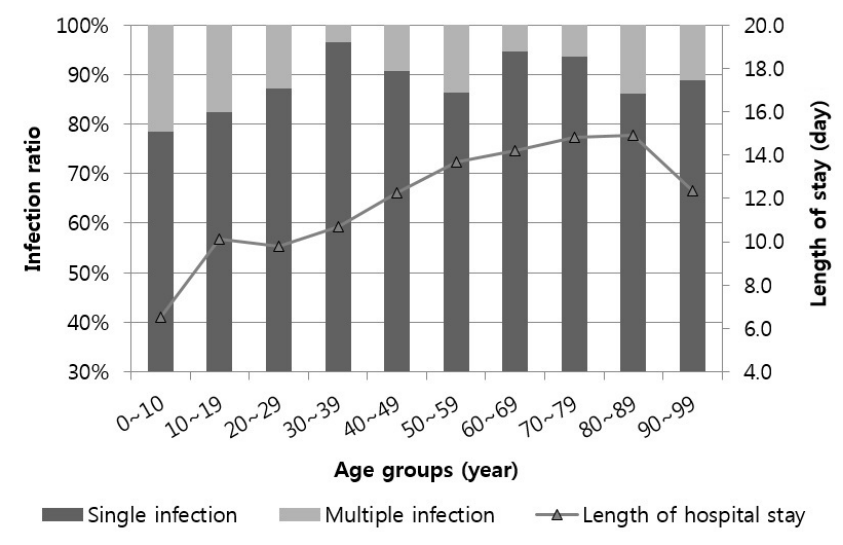

Figure 1. Proportion of single and multiple respiratory virus infections and length of hospital stay in respiratory virus-positive patients, according to age.

\section{DISCUSSION}

This study found no difference in LOS based on sex, but found that the LOS increased with increasing age. Previous studies have reported increasing emergency room admissions with increasing age [8]. And longer LOS among the elderly, with observations that the LOS remains constant despite the administration of antibiotics for viral infections [9]. However, longer LOS in the elderly could also be due to smoking, cardiovascular and/or respiratory diseases, and decreased immunity [10].

Overall, respiratory viruses were detected in 59.9\% $(5,310 / 8,860)$ of patients collected in this study; higher than in other studies conducted at approximately the same time period [11-13]. Of the viruses identified in patients positive for respiratory viruses, HRV was the most prevalent (21.4\%), followed by RSV A (15.8\%) and ADV (15.2\%). Similarly, Seo, et al. (2014) reported that the prevalence of HRV, ADV, and RSV A infections were $31.8 \%$, 
$19.2 \%$, and $17.4 \%$, respectively, in Chung-nam, Korea. A study by Wishaupt, et al. (2011) in the Netherlands reported the following prevalence rates: RSV A, 23.6\%; HRV, 19.4\%; and RSV B infection, 11.5\%. Although the virus detection rates in the present study differed from these other studies, the major viruses identified were the same, namely RSV, HRV, and ADV. In relation to virus types, the LOS of 10.1 days for hCoV OC43 was longer than those of other virus types (range, 8.9-6.2 days); this was significant ( $p=0.030$ ) as was that for INF A (8.9 days), compared with the other virus types ( $p=0.027$ ). However, previous studies have reported different relationships between LOS and virus types. In recently published data, the LOS for patients infected with INF A was reported to be 6.9 days, whereas LOS for patients infected with ADV or hCoV OC43 was 8.2 days and 8.1 days, respectively [14]. In another study, RSV and hMPV infections reportedly resulted in LOS of 4 days and 3 days, respectively [15]. Although RSV B and RSV A infections did not differ in severity, RSV B infection was reported to have a significantly longer recovery time as well as a longer LOS [16]. However, a study that used oxygen therapy, admission to the intensive care unit, and LOS greater than 5 days as indices for severity reported that infections with RSV A were more severe than infections with RSV B [17]. In addition, the INF A virus subtypes H7N9, H5N1, and H1N1 have been reported to have different LOS [18]. These varying LOS by study might be explained by different standards for admission and discharge at individual hospitals. In addition, differences in LOS might be influenced not only by virus type but also by underlying diseases and their severity.

Regarding the relationship between LOS and the number of infections, the LOS with single infections was longer than that with multiple infections (7.3, 6.7 and 6.6 days for double and three or more infections, respectively) by approximately 0.6 days ( $p=0.006$ ). However, the LOS was similar between infections associated with double and three or more respiratory viruses. Papadopoulos, et al (2002) reported a LOS difference between RSV and HRV as single (2.8 days) and multiple infections (4.0 days).
Similarly, there have been reports of longer LOS among pediatric patients with multiple RV infections compared with single infections [19,20]. Moreover, multiple infections have been reported to induce a less favorable prognosis [8]. In contrast, Esposito, et al (2013) reported that the difference in LOS between single (6.9 days) and multiple infections (7.1 days) was not significant. Other studies have reported no difference in clinical symptoms, prognosis, or intensive care unit admission rates between single and multiple infections [21-23], with some reporting less severe disease in patients with multiple respiratory virus infections $[24,25]$. These results might be affected by various conditions, such as underlying diseases, type of virus detected in different geographical regions, and the combination of viruses that caused the multiple infections.

However, further research is required. LOS related to respiratory virus infection was significantly longer for older patients and those infected with hCoV OC43 or INF A. These specific viral infections can cause many complications, particularly cytopenias. Anemia, neutropenia, and thrombocytopenia are common and are reportedly caused by autoimmune mechanisms, including inhibition of progenitor cells in the bone marrow, movement of neutrophils from blood to tissue, and reduction of platelet production or increased destruction of platelets in the spleen or reticuloendothelial system [26,27]. These complications mainly develop in cases of acute respiratory infection and may affect clinical progress $[28,29]$ because they are related both to patient recovery and disease progression. Studies on the severity of complications are important for determining effective treatment.

The present study has some limitations. The study subjects were selected only from the Cheonan area, and the analyses were based on results from a single institution, thus limiting the generalizability of the findings. In addition, as the subject selection did not involve a planned design owing to the retrospective nature of the study, additional examinations could not be performed. Further multicenter studies with a larger number of subjects are needed to clarify our findings. The strengths of 
this study are the long study period of 5 years and the fact that recent data is presented.

In conclusion, the LOS for patients with multiple infections was not longer than that for patients with single infections. These results are anticipated to be useful for developing effective treatment guidelines for respiratory virus infections.

\section{Acknowledgements: None}

Funding: None

Conflict of interest: None

\section{REFERENCES}

1. Asner SA, Science ME, Tran D, Smieja M, Merglen A, Mertz D. Clinical disease severity of respiratory viral co-infection versus single viral infection: a systematic review and meta-analysis. PLoS One. 2014;9:e99392.

2. Nascimento MS, de Souza AV, de Souza Ferreira AV, Rodrigues JC, Abramovici S, da Silva Filho LVF. High rate of viral identification and coinfections in infants with acute bronchiolitis. Clinics. 2010;65:1133-1137.

3. Chawla R, Kansal S, Chauhan M, Jain A, Jibhkate BN. Predictors of mortality and length of stay in hospitalized cases of 2009 influenza A (H1N1): Experiences of a tertiary care center. Indian J Crit Care Med. 2013;17:275-282.

4. Goka E, Vallely P, Mutton K, Klapper P. Influenza A viruses dual and multiple infections with other respiratory viruses and risk of hospitalisation and mortality. Influenza Other Respir Viruses. 2013;7:1079-1087.

5. Calvo C, Garcia-Garcia ML, Blanco C, Vázquez MC, Frías ME, Pérez-Breña $\mathrm{P}$, et al. Multiple simultaneous viral infections in infants with acute respiratory tract infections in Spain. J Clin Virol. 2008;42:268-272.

6. Miron D, Srugo I, Kra-Oz Z, Keness Y, Wolf D, Amirav I, et al. Sole pathogen in acute bronchiolitis: Is there a role for other organisms apart from respiratory syncytial virus? Pediatr Infect Dis J. 2010;29:e7-e10.

7. Richard N, Komurian-Pradel F, Javouhey E, Perret M, Rajoharison A, Bagnaud A, et al. The impact of dual viral infection in infants admitted to a pediatric intensive care unit associated with severe bronchiolitis. Pediatr Infect Dis J. 2008;27:213217.

8. Semple MG, Cowell A, Dove W, Greensill J, McNamara PS, Halfhide C, et al. Dual infection of infants by human metapneumovirus and human respiratory syncytial virus is strongly associated with severe bronchiolitis. J Infect Dis. 2005;191: 382-386.

9. Hernes SS, Hagen E, Quarsten H, Bjorvatn B, Bakke PS. No impact of early real-time PCR screening for respiratory viruses on length of stay and use of antibiotics in elderly patients hospitalized with symptoms of a respiratory tract infection in a single center in Norway. Eur J Clin Microbiol Infect Dis. 2014; 33:359-364.

10. Menéndez R, Ferrando D, Vallés JM, Martínez E, Perpiñá M. Initial risk class and length of hospital stay in community-acquired pneumonia. European Respiratory Journal. 2001;18: 151-156.

11. Lee EK, Lee YY, Choi KH. Epidemiology and clinical features of respiratory viruses in pediatric inpatients in a single medical center in Daegu from 2010 to 2012. Yeungnam Univ J Med. 2013;30:95-100.

12. Seo JJ, Kim MJ, Kim SH, Key HY, Chung JK, Kim ES, et al. Characterization of respiratory viral infection in children in Gwangju. Infect Chemother. 2008;40:218-229.

13. Zhang D, He Z, Xu L, Zhu X, Wu J, Wen W, et al. Epidemiology characteristics of respiratory viruses found in children and adults with respiratory tract infections in southern China. Int J Infect Dis. 2014;25:159-164.

14. Seo YB, Song JY, Choi MJ, Kim IS, Yang TU, Hong KW, et al. Etiology and clinical outcomes of acute respiratory virus infection in hospitalized adults. Infect Chemother. 2014;46: 67-76.

15. Widmer K, Griffin MR, Zhu Y, Williams JV, Talbot HK. Respiratory syncytial virus- and human metapneumovirus- associated emergency department and hospital burden in adults. Influenza Other Respir Viruses. 2014;8:347-352.

16. Yoon GH, Kim YH. The clinical characteristics in infantile bronchiolitis and pneumonia according to respiratory syncytial virus subgroups: experience of single tertiary medical center from 2010 to 2012. Allergy Asthma Respir Dis. 2013;1:84-89.

17. Gilca R, De Serres G, Tremblay M, Vachon ML, Leblanc E, Bergeron MG, et al. Distribution and clinical impact of human respiratory syncytial virus genotypes in hospitalized children over 2 winter seasons. J Infect Dis. 2006;193:54-58.

18. Wang C, Yu H, Horby PW, Cao B, Wu P, Yang S, et al. Comparison of patients hospitalized with influenza A subtypes H7N9, H5N1, and 2009 pandemic H1N1. Clin Infect Dis. 2014;58: 1095-1103.

19. Drews AL, Atmar RL, Glezen WP, Baxter BD, Piedra PA, Greenberg SB. Dual respiratory virus infections. Clin Infect Dis. 1997;25:1421-1429.

20. Papadopoulos NG, Moustaki M, Tsolia M, Bossios A, Astra E, Prezerakou A, et al. Association of rhinovirus infection with increased disease severity in acute bronchiolitis. Am J Respir Crit Care Med. 2002;165:1285-1289.

21. Echenique IA, Chan PA, Chapin KC, Andrea SB, Fava JL, Mermel LA. Clinical characteristics and outcomes in hospitalized patients with respiratory viral co-infection during the 2009 H1N1 influenza pandemic. PLoS One. 2013;8:e60845.

22. Maletzky AJ, Cooney MK, Luce R, Kenny GE, Grayston, JT. Epidemiology of viral and mycoplasmal agents associated with childhood lower respiratory illness in a civilian population. J Pediatr. 1971;78:407-414.

23. Portnoy B, Eckert HL, Hanes B, Salvatore MA. Multiple respiratory virus infections in hospitalized children. Am J Epidemiol. 1965;82:262-272.

24. Martin ET, Kuypers J, Wald A, Englund JA. Multiple versus single virus respiratory infections: viral load and clinical disease se- 
verity in hospitalized children. Influenza Other Respir Viruses. 2012;6:71-77.

25. Palomino MA, Larraino C, Villagra E, Camacho J, Avendaño LF. Adenovirus and respiratory syncytial virus-adenovirus mixed acute lower respiratory infections in Chilean infants. Pediatr Infect Dis J. 2004;23:337-341.

26. Flaujac C, Boukour S, Cramer-Bord CE. Platelets and viruses: an ambivalent relationship. Cell Mol Life Sci. 2010;67:545-556.

27. Newburger PE, Boxer LA. Leukopenia. In: Kliegman RM, Stanton B, editors. Nelson textbook of pediatrics. 19th ed. Philadelphia: Elsevier Saunders; 2011. p746-752.

28. Park IH, Lee SH, You ST, Choi DY. Hematologic complication of respiratory virus infection. Korean J Pediatr Infect Dis. 2013;
20:178-185.

29. Cho KS. Characterization and Outbreak Pattern of Influenzavirus Isolated in Busan Area, 2000-2002 years. Korean J Clin Lab Sci. 2003;35:1-8.

30. Esposito S, Daleno C, Prunotto G, Scala A, Tagliabue C, Borzani I, et al. Impact of viral infections in children with community-acquired pneumonia: results of a study of 17 respiratory viruses. Influenza Other Respir Viruses. 2013;7:18-26.

31. Wishaupt JO, Russcher A, Smeets LC, Versteegh FG, Hartwig NG. Clinical impact of RT-PCR for pediatric acute respiratory infections: a controlled clinical trial. Pediatrics. 2011;128: e1113-e1120. 